Article

\title{
A Novel Low-Temperature Non-Corrosive Sulfate/Sulfide Scale Dissolver
}

\author{
Hany Gamal $^{1}\left(\mathbb{D}\right.$, Salaheldin Elkatatny ${ }^{*} \mathbf{1}^{\mathbb{D}}$, Dhafer Al Shehri ${ }^{1} \mathbb{D}$ and Mohamed Bahgat ${ }^{2}$ \\ 1 College of Petroleum Engineering \& Geosciences, King Fahd University of Petroleum \& Minerals, \\ Dhahran 31261, Saudi Arabia; g201706870@kfupm.edu.sa (H.G.); alshehrida@kfupm.edu.sa (D.A.S.) \\ 2 Rosewell Energy, 327 El-Horreya Road, Cleopatra, Alexandria 21500, Egypt; \\ mohamed.bahgat2@outlook.com \\ * Correspondence: elkatatny@kfupm.edu.sa; Tel.: +966-594-663-692
}

Received: 4 February 2020; Accepted: 15 March 2020; Published: 20 March 2020

check for updates

\begin{abstract}
The oil and gas production operations suffer from scale depositions. The scale precipitations have a damaging impact on the reservoir pores, perforations, downhole and completion equipment, pipeline network, wellhead chokes, and surface facilities. Hydrocarbon production possibly decreased because of the scale accumulation in the well tubular, leading to a well plugging, this requires wells to be shut-in in severe cases to perform a clean-out job. Therefore, scale deposition is badly affecting petroleum economics. This research aims to design a scale dissolver with low cost, non-damaging for the well equipment and has a high performance at the field operating conditions. This paper presents a novel non-corrosive dissolver for sulfate and sulfide composite scale in alkaline $\mathrm{pH}$ and works at low-temperature conditions. The scale samples were collected from a production platform from different locations. A complete description of the scale samples was performed as X-ray diffraction (XRD) and X-ray fluorescence (XRF). The new scale dissolver was prepared in different concentrations to examine its dissolution efficiency for the scale with time at low temperatures. The experimental design studied the solid to fluid ratio, temperature, solubility time, and dissolution efficiency in order to achieve the optimum and most economic performance of solubility in terms of high dissolution efficiency with the smallest possible amount of scale dissolver. A solubility comparison was performed with other commercial-scale-dissolvers and the corrosion rate was tested. The experimental work results demonstrated the superior performance of the new scale dissolver. The new scale dissolver showed a solubility efficiency of $91.8 \%$ at a low temperature of $45^{\circ} \mathrm{C}$ and $79 \%$ at $35{ }^{\circ} \mathrm{C}$. The new scale dissolver showed a higher solubility ratio for the scale sample than the ethylenediaminetetraacetic acid (EDTA) (20 wt. \%), diethylenetriamine pentaacetic acid (DTPA) (20 wt. \%), and HCl (10 wt. \%). The corrosion rate for the new non-corrosive dissolver was $0.01357 \mathrm{~kg} / \mathrm{m}^{2}\left(0.00278 \mathrm{lb}\right.$. $\left./ \mathrm{ft}^{2}\right)$ which was considered a very low rate and non-damaging for the equipment. The low corrosive effect of the new dissolver will save the extra cost of adding the corrosion inhibitors and save the equipment from the damaging effect of the corrosive acids.
\end{abstract}

Keywords: sulfate scale; sulfide scale; scale dissolver; low $\mathrm{pH}$; corrosion rate; environmentally friendly

\section{Introduction}

The precipitations of the scales on the internal surfaces of the pipelines, surface facilities, and downhole equipment cause a lot of operational problems and, in severe cases, this might lead to shutting down the well. In the daily operation reports, scale deposition is very common and is a nightmare for the production and process engineers. The main problems of the scale depositions are a reduction in the inner diameter of the production tubes, reduction in the well production and pressure, surface and subsurface equipment failure, perforations, and formation damage in the reservoir [1-4]. 
The wettability of the reservoir rock could be changed due to the deposition of iron sulfide [5]. Not only the production wells suffer from the scale, but even the water source wells, injection wells, and disposal wells have scale depositions [5,6]. The scale was deposited on the sand face and plugged part of the formation pores and, therefore, it will reduce the well productivity or the well injectivity in the case of production or injection wells [7-9].

Sulfate and sulfide mixture scales are considered to be common scale types in the oil and gas production due to the different minerals and brines that coexist in the production stream, reservoir formation water, and injected water in the petroleum reservoir. Formation water in the reservoir and seawater is an important source for the brines, as it is used for injection operations to enhance reservoir recovery. Formation water contains sulfate ions with low concentrations, and calcium, and barium with high concentrations, while seawater contains sulfate ions with high concentrations and barium and calcium ions with low concentrations. Therefore, the incompatibility between the two types of water sources will lead to a scale forming as barium sulfate and calcium sulfate [9]. Pyrrhotite ( $\left.\mathrm{Fe}_{7} \mathrm{~S}_{8}\right)$, troilite (FeS), mackinawite $\left(\mathrm{Fe}_{9} \mathrm{~S}_{8}\right)$, pyrite $\left(\mathrm{FeS}_{2}\right)$, marcasite $\left(\mathrm{FeS}_{2}\right)$, greigite $\left(\mathrm{Fe}_{3} \mathrm{~S}_{4}\right)$, sphalerite $(\mathrm{ZnS})$, galena $(\mathrm{PbS})$ are different sulfide scales. Hydrogen sulfide gas is considered as a common source of sulfides. Sulfates as scales are usually precipitated in the oil and gas fields as gypsum $\left(\mathrm{CaSO}_{4} \cdot 2 \mathrm{H}_{2} \mathrm{O}\right)$, anhydrite $\left(\mathrm{CaSO}_{4}\right)$, barite $\left(\mathrm{BaSO}_{4}\right)$, hemihydrate $\left(\mathrm{CaSO}_{4} \cdot 5 \mathrm{H}_{2} \mathrm{O}\right)$, celestite $\left(\mathrm{SrSO}_{4}\right)$. Sulfide scales are deposited when hydrogen sulfide reacts with minerals such as iron, zinc, and lead due to the incompatibility of brines. There are important factors that control the scale deposition, such as operating temperature and pressure, the chemical reaction equilibria, $\mathrm{pH}$, exposure time for interactions, evaporation, and ionic strength [10]. Barium sulfate-, calcium sulfate-, and strontium-based scales are the most common scale types in the oil and gas fields, in addition to oxides and hydroxides $(\mathrm{Fe}, \mathrm{Mg})$, carbonates such as $(\mathrm{Ca}$, $\mathrm{Mg}$, $\mathrm{Fe}$ ), and sulfides (Fe) [11,12]. The most common sulfide scale is iron sulfide. The locations of scale depositions differ due to temperature and pressure conditions. Lead and zinc sulfide scales are found to be deposited in the shallower part of the well completion, control valves, and in the subsurface safety control valves $[13,14]$. Sulfate scales were found to be deposited by the seawater injection operations, and such a scale is one of the hardest scales to be removed as it has low acid-solubility. The incompatibility of different water sources is the reason behind sulfate scale deposition [15]. The barium sulfate scale is also one of the most common scales in the petroleum industry, as barium sulfate is one of the drilling mud additives as a weighting material. Mud invasion into the drilled formation will carry the barium sulfates, depositing them in the formation pores that cause formation damage and permeability reduction [16]. Calcium sulfate scale is found to be precipitated around the electrical submersible pump in the well and also in the reservoir zone $[17,18]$. Strontium sulfate was commonly related to the surface facilities of oil production. The main source of the strontium sulfate scale is seawater, which contains strontium ions in its mineral composition [19].

\section{Scale Removal}

Scale removal in the oil and gas field is a difficult and complicated operation. Chemical dissolvers and mechanical removal are usually used together to remove the deposited scales. the design of the scale dissolver method should consider economic and technical aspects. It should be low-cost, non-damaging to the surface facilities, well tubed, equipped, and contain reservoir rock. In addition, it should have a high degree of thermal stability, be environmentally friendly and should not produce $\mathrm{H}_{2} \mathrm{~S}$ gas after scale dissolution $[20,21]$. The scale treatment cost is considered to be very high, especially if it stops oil and gas production [22]. Therefore, scale inhibitors are considered to be an efficient way to reduce or prevent scale formation and the scale inhibitors have a wide application in oil fields. Scale inhibitors succeeded in preventing the formation of different types of scales $[9,23,24]$. The success of the scale inhibitor function to prevent scale formation depends on the design of the inhibitor's composition, the dose, and its efficiency under the operating pressure and temperature conditions. An inefficient design for the scale inhibitors will lead to scale deposition and the use of the scale dissolver to remove the scale precipitations [25]. BinMerdhah et al., [9] stated that the scale might be 
deposited due to mixing incompatible brines, pressure and temperature change, or the evaporation of brines.

Formulating a chemical dissolver to remove such scale types is a very difficult task due to the variety of minerals that exist in the same well. The reason for that is the different chemical reactions between the dissolver and the different scale minerals. Many types of scales are water-soluble, such as sodium chloride, while there are acid-soluble scales, such as calcium carbonate, iron sulfide, and iron oxide [4]. Another challenge in the removal design is $\mathrm{pH}$ control. Calcium and barite sulfate scales removal are not dependent on the brine $\mathrm{pH}$, however, the scales such as iron sulfide and carbonate depositions depend on the brine $\mathrm{pH}$. Calcium sulfate has lower solubility at low-pressure conditions, and is less soluble in a dissolver solution with a high $\mathrm{pH}$ [26].

Chemically, many organic and inorganic chemicals are commonly used for scale removal in the oil and gas fields. The chemical composition of the existing scale is a very important factor for the dissolver design [27]. In the real field scales, a hydrocarbon layer coats the scale body and prevents the acid from contact with the scale and, therefore, surfactants are usually used to solve this interaction matter and enhance the scale-dissolver interactions.

Hydrochloric acid $(\mathrm{HCl})$ is the most common acid used for scale removal in the petroleum industry [28]. However, using $\mathrm{HCl}$ for scale removal cannot dissolve many scale types, expensive, corrosive, and generates toxic gas $\mathrm{H}_{2} \mathrm{~S}$ and therefore other additives must be added to control the reaction [5,29-31]. $\mathrm{HCl}$ can dissolve zinc sulfide [32], and few iron sulfide scales as troilite and pyrrhotite; however, pyrite and marcasite are difficult to dissolve with $\mathrm{HCl}$ [31]. Sulfate scales such as barium, calcium, and strontium sulfates were found to have low $\mathrm{HCl}$ acid-solubility [22,33].

Acetic acid, formic acid, maleic acid, and citric acid are different types of organic acids and they are used for scale removal for high-pressure, high-temperature (HPHT) reservoirs instead of $\mathrm{HCl}$ [34-36]. However, the organic acids have a lower dissolution efficiency than $\mathrm{HCl}$ [35], they are less corrosive and have a long-time reaction. Chelating agents are considered to be an alternate solution to organic and inorganic acids for the removal of scale from formations.

Another common scale dissolver is the chelating agents, which are a more environmentally friendly solution, and less corrosive [37]. The most commonly used chelating agents are ethylenediaminetetraacetic acid (EDTA), hydroxyethyl ethylene diamine tetraacetic acid (HEDTA), hydroxyethyl iminodiacetic acid (HIDA), glutamic acid di-acetic acid (GLDA), diethylenetriamine pentaacetic acid (DTPA), nitrilotriacetic acid (NTA), and methylglycinediacetic acid (MGDA). Studies were performed to provide a scale dissolver using the chelating agent for the pyrite iron sulfide scale with more than $80 \%$ pyrite, the chemical formulation for the dissolver contained $20 \mathrm{wt}$. \% DTPA at $\mathrm{pH} 11$ with $9 \mathrm{wt}$. \% potassium carbonate as a catalyst. The formulation succeeded at dissolving the scale with an efficiency of $85 \%$ at a temperature of $70{ }^{\circ} \mathrm{C}$ for $48 \mathrm{~h}[38,39]$. Nitrilotriacetic acid (NTA) is one of the chelating agents used for scale removal, and it has a biodegradability level higher that EDTA and DTPA [40].

The $\mathrm{pH}$ has a great effect on the scale treatment process. The acids that are used for scale removal with a lower $\mathrm{pH}$ will greatly affect the well tubular integrity and increase the corrosion rate. The treatment design has recently been used to target the green scale removal with a basic $\mathrm{pH}$ to protect the surface facilities and downhole equipment from damage [41,42]. The combination of EDTA with tetrakis (hydroxymethyl) phosphonium salts (THPS) was studied to provide a scale dissolver with high $\mathrm{pH}$ and that helped to reduce the corrosion rate and the amount of corrosion inhibitor that is usually added to the removal solution [42]. Ramanathan et al., [43] studied the effect of pH control and treatment time on the chelating agent. The study determined the optimum $\mathrm{pH}$ and time of treatment for the removal of iron sulfide scale.

The objective of this paper is to introduce a novel non-corrosive dissolver to remove sulfate and mixed sulfide scale. The novelty in the new proposed non-corrosive dissolver is its high $\mathrm{pH}$ value with a very low corrosion rate, less than the acceptable limit by the oil and gas industry, based on the recent studies, to provide a basic $\mathrm{pH}$ scale dissolver. In addition, the new dissolver efficiently provided a high dissolution efficiency for the scale at a low-temperature condition of $45^{\circ} \mathrm{C}$. 


\section{Materials and Experimental Work}

\section{Materials Description}

Composite scale samples from the sulfate and sulfide mixed scale were collected from an offshore platform. The platform is produced from a sandstone reservoir with an average depth of $2743.2 \mathrm{~m}$, average reservoir pressure of $10.34-12.41 \mathrm{MPa}$, and a temperature range $40-60^{\circ} \mathrm{C}$. Field production has a high water-cut ratio of $70 \%$.

The samples were collected from different locations with different physical shapes. Sample 1 is a dry rigid scale, has regular shape pieces, and was precipitated near or at the well surface. Sample 2 is a black metallic scale, with irregular shapes, and has a noticeable hydrocarbon smell. The third sample 3 is a dry rusty scale, with irregular shape pieces, and does not have a hydrocarbon smell. Samples 2 and 3 were collected from the production separator. Figure 1 illustrates the collected three samples.

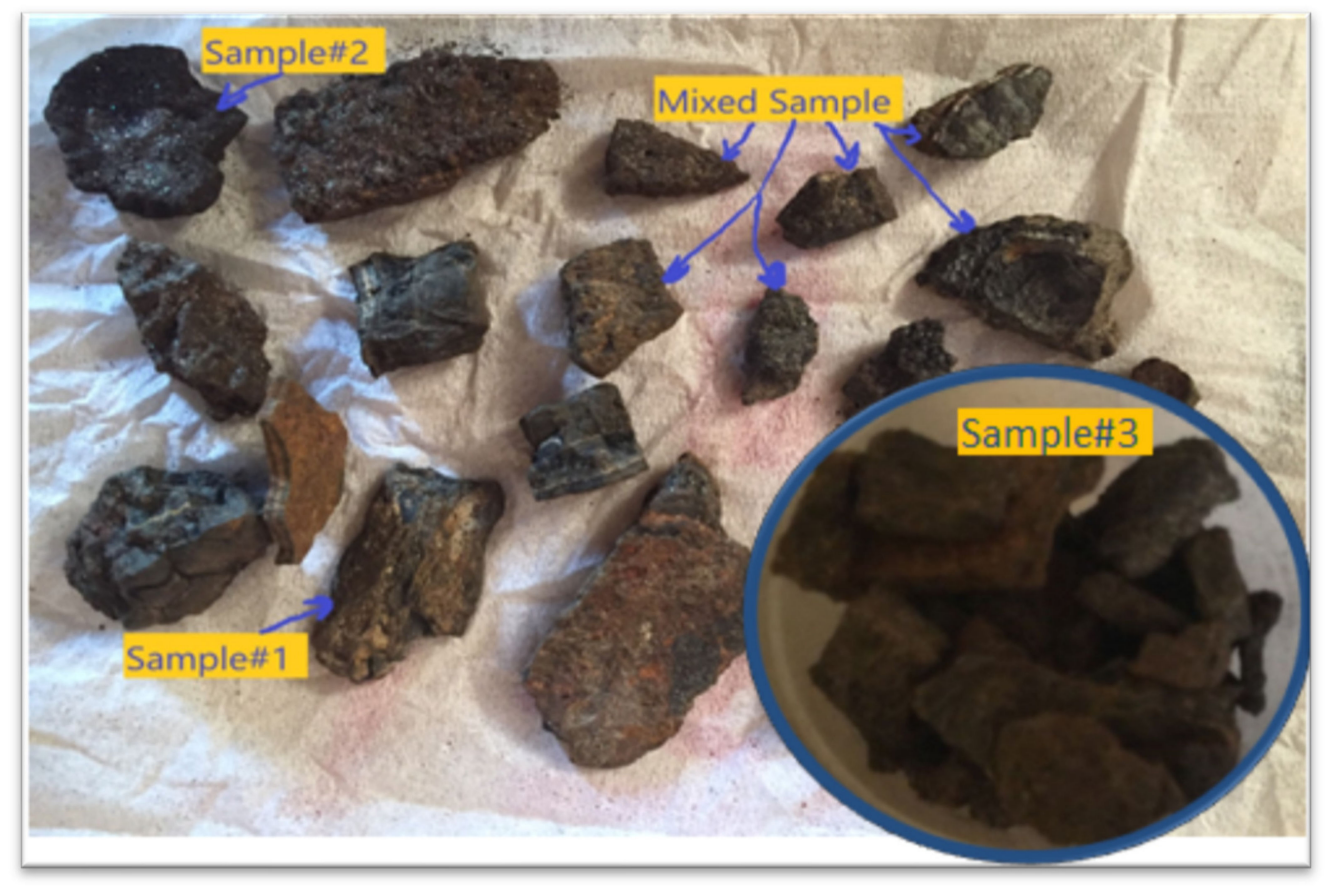

Figure 1. The scale samples as collected from the field.

The mineralogical compositional analysis for the three samples was determined using the $X$-ray powder diffraction (XRD). The diffraction pattern was generated by a theta-2theta scanning diffractometer, while the X-ray fluorescence (XRF) was performed to obtain the elemental composition of the scale samples. Table 1 lists the XRD of the three scale samples as a component compositional percentage in each sample. The samples have a high percentage of strontium-rich barite scale, hokutolite with a chemical formula of $(\mathrm{BaPb})\left(\mathrm{SO}_{4}\right)_{2}$ which is a solid-solution binary system of the barite $\left(\mathrm{BaSO}_{4}\right)$ and anglesite $\left(\mathrm{PbSO}_{4}\right)$ [44]. The scale composition also contains lead sulfide (galena, $\mathrm{PbS}$ ) with a portion range from $24.5 \%$ to $39.3 \%$. Another bulk sample was recovered from an old plugged pipeline, as shown in Figure 2. The bulk sample weighed an average of $2 \mathrm{~kg}$.

Table 1. X-ray powder diffraction (XRD) analysis of the scale field samples.

\begin{tabular}{ccccc}
\hline Component & Chemical Formula & Sample 1 Percentage, \% & Sample 2 Percentage, \% & Sample 3 Percentage, \% \\
\hline Hokutolite & $\left(\mathrm{BaPb}_{2}\left(\mathrm{SO}_{4}\right)_{2}\right.$ & 16.8 & 13.5 & 14.4 \\
Barite, Sr-rich & $\mathrm{Ba}_{0.75} \mathrm{Sr}_{0.25} \mathrm{SO}_{4}$ & 58.7 & 47.2 & 50.1 \\
Galena & $\mathrm{PbS}$ & 24.5 & 39.3 & 35.5 \\
\hline
\end{tabular}




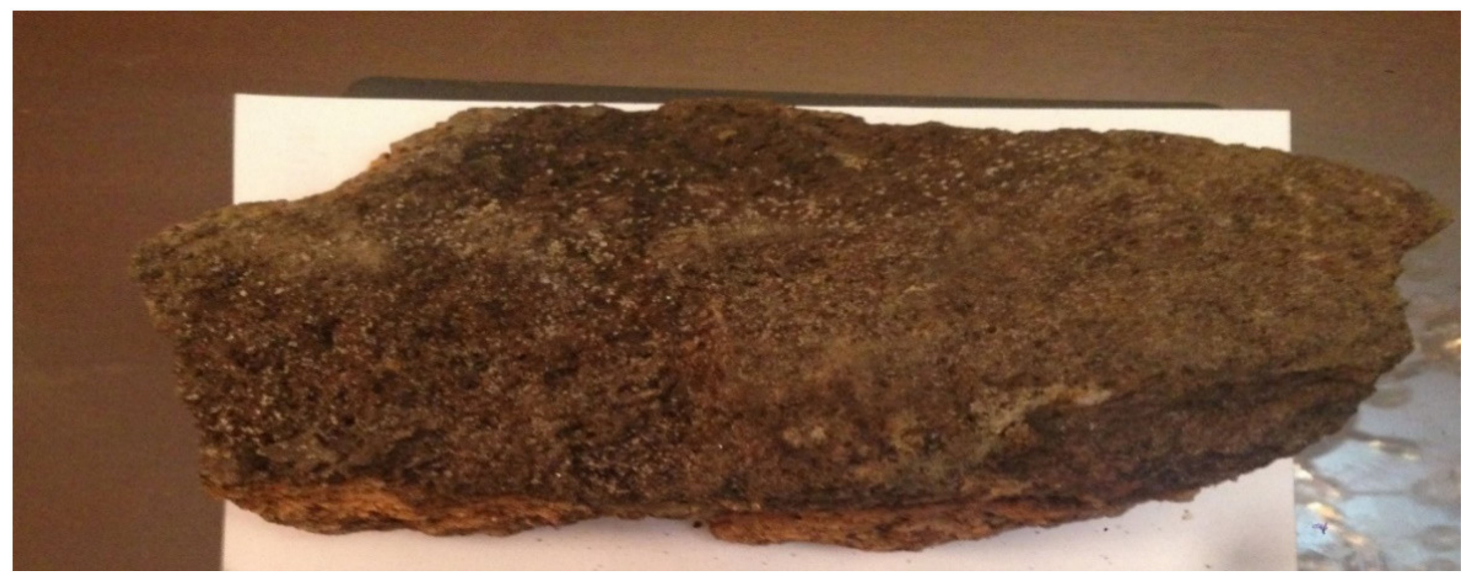

Figure 2. Bulk scale sample collected from a plugged pipeline.

The bulk sample was crushed and tested with a magnet. It was found that about $12 \%$ of the sample stuck to the magnet, therefore, this is an indication that the sample has a high percentage of amorphous iron minerals. The chemical composition of the bulk sample is presented in Table 2. This shows that the bulk sample contains a composite scale of paraffin wax, asphaltene, chlorides, calcium carbonate, a mixed iron, lead and zinc sulfides, and mixed barium and strontium sulfates.

Table 2. The chemical composition of the bulk sample.

\begin{tabular}{cc}
\hline Composition & Weight (wt.) \% \\
\hline Paraffin Wax & 3.3 \\
Asphaltene & 0.5 \\
Chlorides & 2.0 \\
Iron Sulfide & 3.5 \\
Lead Sulfide & 2.5 \\
Zinc Sulfide & 7.6 \\
Calcium Carbonate & 4.1 \\
Barium Sulfate & 50.0 \\
Strontium Sulfate & 26.5 \\
\hline
\end{tabular}

For XRF, results are displayed in Table 3 for samples 1, 2, 3 and the bulk sample, respectively. As shown in the XRF, the barium $(\mathrm{Ba})$ represents the highest percentage in the chemical composition in all the samples, followed by sulfur $(\mathrm{S})$, lead $(\mathrm{Pb})$, and strontium $(\mathrm{Sr})$. The remaining as zinc $(\mathrm{Zn})$, silicon $(\mathrm{Si})$, chlorine $(\mathrm{Cl})$ share the smallest portion in the scale composition. The bulk sample has calcium (Ca), and iron (Fe) within its composition.

Table 3. XRF analysis of the scale field samples.

\begin{tabular}{ccccc}
\hline Element & Sample\#1, $\%$ & Sample\#2, $\%$ & Sample\#3, $\%$ & Bulk Sample, $\%$ \\
\hline $\mathbf{F e}$ & 0.00 & 3.83 & 0.00 & 4.40 \\
$\mathbf{C a}$ & 0.00 & 0.00 & 0.00 & 17.13 \\
$\mathbf{S}$ & 23.69 & 16.16 & 28.61 & 12.00 \\
$\mathbf{P b}$ & 21.24 & 30.23 & 22.84 & 9.27 \\
$\mathbf{B a}$ & 36.45 & 31.86 & 30.74 & 30.52 \\
$\mathrm{Sr}$ & 17.84 & 17.63 & 14.96 & 21.41 \\
$\mathbf{Z n}$ & 0.00 & 0.00 & 1.30 & 1.06 \\
$\mathbf{S i}$ & 0.38 & 0.09 & 0.00 & 1.58 \\
$\mathbf{C l}$ & 0.40 & 0.20 & 1.56 & 2.64 \\
\hline
\end{tabular}

As discussed previously in the literature, the reason behind these types of scale depositions is the incompatibility between the formation water and injected water with different brines $[9,15]$. 
Table 4 shows the water analysis for the water sample from the field and represents a mixture of different ions. The table shows the chemical analysis of the field water in terms of the ion concentration and its reacting value. Chemists use the reacting values for two purposes: first, to determine the accuracy of the water analysis and second, to obtain reliable factors to be used in the construction of hypothetical combinations for scale prediction. The geo-chemical analysis of the field water enhances the expectation of the formation of different composite scales.

Table 4. The chemical analysis for the field water.

\begin{tabular}{ccccc}
\hline Ions & & $\mathbf{M g} / \mathbf{L}$ & Reacting Value & \% Reacting Value \\
\hline Sodium & $\mathrm{Na}$ & 14,800 & 643.8 & 27.98 \\
Calcium & $\mathrm{Ca}$ & 7780 & 388.22 & 16.87 \\
Barium & $\mathrm{Ba}$ & 956 & 78.58 & 3.42 \\
Sulfate & $\mathrm{SO}_{4}$ & 3390 & 70.51 & 3.06 \\
Chloride & $\mathrm{Cl}$ & 38,700 & 1091.34 & 47.44 \\
Silicon & $\mathrm{Si}$ & 15 & 0.76 & 0.03 \\
Bicarbonate & $\mathrm{HCO}_{3}$ & 4.31 & 0.44 & 0.02 \\
Lead & $\mathrm{Pb}$ & 432 & 8.98 & 0.39 \\
Strontium & $\mathrm{Sr}$ & 619 & 10.15 & 0.44 \\
Zinc & $\mathrm{Zn}$ & 81 & 6.66 & 0.29 \\
Boron & $\mathrm{B}$ & 14 & 1.15 & 0.05 \\
Total Dissolved Solids (TDS) & 66,791 & & \\
\hline
\end{tabular}

The new scale dissolver for the sulfate and sulfide mixture composite scale samples was formulated, and the chemical composition is listed in Table 5 . The scale dissolver is mainly composed of chelating agents such as ethylenediamine, nitrilotriacetic acid (NTA), ethylenediaminetetraacetic acid (EDTA) which are the most commonly used chelating agents in the oil field [45]. The formulation of the new scale dissolver contains chloroacetic acid, which is an organic acid salt, as well as being a basic component in generating chelating products, in addition to surfactant. The weight percent for the main components has a lower and upper limit, as the scale dissolver can be mixed in different concentrations.

Table 5. The chemical composition for the new scale dissolver.

\begin{tabular}{cc}
\hline Component & Weight \% \\
\hline Ethylenediamine & $3 \%-5 \%$ \\
Nitrilotriacetic acid (NTA) & $5 \%-10 \%$ \\
Chloro Acetic Acid & $10 \%-30 \%$ \\
Water & $40 \%-70 \%$ \\
\hline
\end{tabular}

The fluid properties were measured at ambient conditions, with 1.16 specific gravity, and its $\mathrm{pH}$ was 12.5, as the scale dissolver was designed to dissolve the scale at a high $\mathrm{pH}$ to protect the well tubular from corrosion and did not affect the surface pipelines' integrity. The corrosion effect is considered to be a damaging effect for most of the commonly used scale dissolver acids $[46,47]$. The fluid has a clear to slight yellow color with an amine-like odor.

Additionally, commercial chemicals were used to compare the new removal efficiency, such as EDTA (20 wt. \%), DTPA (20 wt. \%), and $\mathrm{HCl}(10 \mathrm{wt} . \%)$. The commercial scale dissolver was obtained from service companies and the dissolution performance was conducted for the new scale dissolver and the commercial dissolvers.

\section{Methods}

\subsection{Static Solubility Test}

This experimental laboratory work was designed to evaluate the dissolution efficiency for the new scale dissolver at a high $\mathrm{pH}$. While testing its solubility, important parameters could affect the solubility 
optimization, such as the solid to fluid ratio, temperature, static or dynamic condition, solubility time, and dissolution efficiency, in order to achieve the optimum and most economical solubility in terms of high-dissolution efficiency with the smallest possible amount of the scale dissolver.

The following procedure was conducted for the bulk sample:

1. Put $100 \mathrm{~mL}$ of the scale dissolver in an oven at $45^{\circ} \mathrm{C}$ for $5 \mathrm{~min}$;

2. Prepare $4.0 \mathrm{~g}$ from the bulk scale as determined, with weight as (W1);

3. Add the solid scale to the dissolver solution inside a test tube in the water bath at a temperature of $45^{\circ} \mathrm{C}$ for a time duration of 18 to $20 \mathrm{~h}$;

4. Once the test period is completed, remove the test tube to cool down;

5. After the cooling, prepare to separate the remaining solids from the solution by using a filter paper to filter the test fluid using a vacuum pump;

6. Measure the weight of the filter paper as dry and then filtrate the solution from the solids;

7. Dry the remaining solid in a static oven for 1 to $2 \mathrm{~h}$.;

8. Measure the weight of the solids with the filter paper after drying process as (W2);

9. Measure the weight of the remaining solids (W3 = W2-weight of filter paper);

10. Measure the scale dissolver dissolution efficiency $=[(\mathrm{W} 1-\mathrm{W} 3) / \mathrm{W} 1] \times 100$.

Solubility Test for Fine Sample (5 Mesh Size)

The solubility test was performed for the fine-scale sample of five mesh sizes with a nominal sieve opening of $4.0 \mathrm{~mm}$. The same procedures were conducted for the mesh size scale samples as for the bulk sample. However, the solid to liquid ratio was $2.0 \mathrm{~g}$ from the fine-scale to $20 \mathrm{~mL}$ from the new scale dissolver. The solid to liquid ratio is considered an important factor in the solubility design [21,48]. The solid amount represents how much of the scale was deposited and plugged the internal pipeline capacity for the fluid flow. The scale density and volume of the internal tubular diameter are used together to determine the scale solid weight that has to be removed using the scale dissolver $[16,49]$. The volume of the scale dissolver is determined from the dissolution efficiency within the solubility test. A lower amount from the scale dissolver is better from an economic point of view [5].

\subsection{Corrosion Test}

The scale dissolver that is usually used for the scale removal operation should be tested for its corrosion to mitigate the surface and the downhole equipment deterioration. The corrosion test is performed on the scale dissolver fluid by submersing a steel coupon into the scale dissolver and putting them in an aging cell under the designated pressure and temperature. The exposure time of the steel to the scale dissolver extends for $6 \mathrm{~h}$ to evaluate the fluid 'seffect on the coupon and to mimic the real field treatment operation time. The weight loss in the steel coupon after the interaction with the fluid is calculated and the weight loss per unit surface area of the coupon represents the corrosion rate for that fluid. A lower corrosion rate is the target for any scale removal design, as it will save the equipment from damage. At the condition of high temperature, the corrosion inhibitors are added to the scale dissolver to reduce the corrosion effect on the well tubing and surface lines. In addition, intensifiers are added to the corrosion inhibitors to enhance the inhibitor's effectiveness for the treatment with a long time, or in the case of high acid concentrations, or with the condition of high temperature [50,51].

The corrosion test was performed as follows:

1. Prepare a volume of $350 \mathrm{~mL}$ from the new scale dissolver at $\mathrm{pH} 12.5$ and put in the aging cell that was designed for the corrosion test, as in Figure 3;

2. Use a steel coupon and measure its weight, dimensions in terms of thickness and surface area;

3. Immerse the coupon into the scale dissolver with a wire to allow the fluid to touch all the steel surfaces; 
4. Close the aging cell and put it into the oven under a temperature of $90^{\circ} \mathrm{C}$ and ambient pressure conditions for a time of $6 \mathrm{~h}$;

5. After the designed time, allow the cell to cool outside and, after cooling down, measure the coupon weight and its dimensions compared to before the fluid exposure;

6. Calculate the corrosion rate as the weight loss per unit surface area of the coupon.

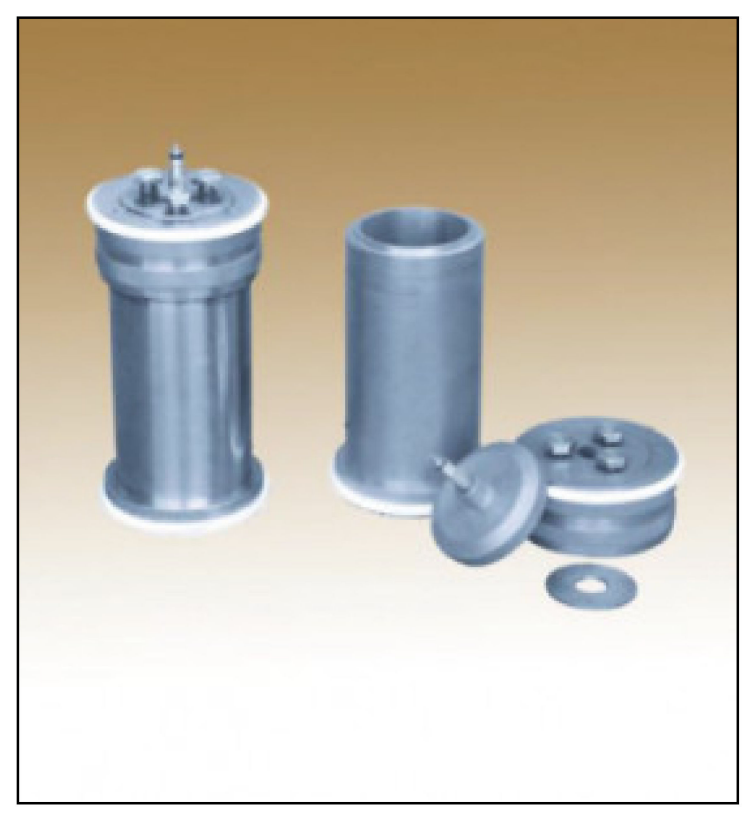

Figure 3. The aging cell used for the corrosion test.

\section{Results and Discussion}

This section shows the results for the experimental work that was done to evaluate the new scale dissolver's efficiency for removing the composite sulfate and sulfide mixture scale sample. The results show the solubility test results in terms of the scale dissolution efficiency and categorize the different shapes and sizes used for the scale samples as bulk or fine. A comparison is made between the solubility efficiency of the new scale dissolver and another commercial scale dissolver that is usually used in the field treatment.

\subsection{Solubility Test Results}

The solubility efficiency for the new scale dissolver was performed using different concentrations of the new scale dissolver to dissolve the scale samples. The fine-scale sample that was used is a mixture of the previously described small samples 1, 2, and 3 in Figure 1. The bulk sample was the scale sample collected from a plugged pipeline, as shown in Figure 2. The dissolution efficiency for the scale samples with different concentrations of the new scale dissolver at $45^{\circ} \mathrm{C}$ after $18 \mathrm{~h}$ is shown in Figure 4. The results in Figure 4 showed that the five different concentrations of the new dissolver can dissolve the fine-scale sample with a dissolution efficiency ranging from $44.1 \%$ to $81.17 \%$. As concentration 1 showed the lowest dissolution efficiency, while concentration 3 reached the highest dissolution efficiency of $81.17 \%$. for the bulk sample, the results showed that concentration 5 had the highest dissolution efficiency of $69.78 \%$, while concentration 3 had a $52.79 \%$ dissolution efficiency. 


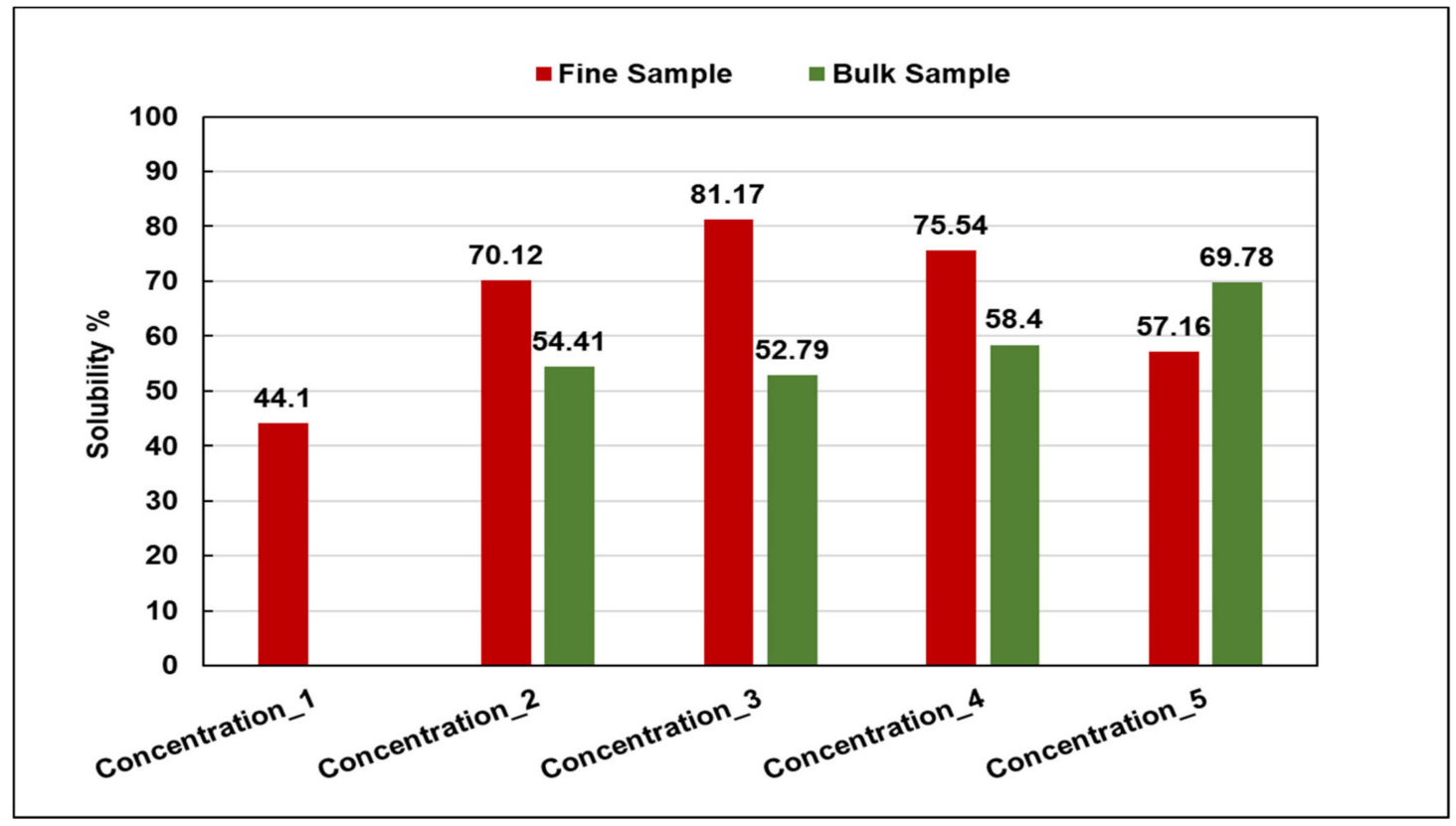

Figure 4. The dissolution efficiency for the scale samples with different concentrations of the new scale dissolver at $45^{\circ} \mathrm{C}$ after $18 \mathrm{~h}$.

The static solubility test for the fine-scale sample was performed at temperatures of 45 and $35{ }^{\circ} \mathrm{C}$ and the solubility time was extended to $20 \mathrm{~h}$. The solubility test was performed using more than one concentration of the new scale dissolver, as shown in Table 6 . The results showed that the new scale dissolver with concentration 2 showed a dissolution efficiency of $79.4 \%$ at a temperature of $45^{\circ} \mathrm{C}$, and achieved a $68.7 \%$ dissolution efficiency at a temperature of $35^{\circ} \mathrm{C}$. In addition, the new scale dissolver was used for the solubility of the powder scale sample for $24 \mathrm{~h}$ and its dissolution efficiency was $91.8 \%$ from the scale at $45{ }^{\circ} \mathrm{C}$ and $79 \%$ at $35^{\circ} \mathrm{C}$.

Table 6. Solubility test results with the new scale dissolver different concentrations at 45 and $35^{\circ} \mathrm{C}$.

\begin{tabular}{|c|c|c|c|c|}
\hline \multirow{2}{*}{ New Scale Dissolver } & \multirow{2}{*}{ Scale Sample } & \multirow{2}{*}{ Time, hr.'s } & \multicolumn{2}{|c|}{ Solubility, \% } \\
\hline & & & $45^{\circ} \mathrm{C}$ & $35^{\circ} \mathrm{C}$ \\
\hline Concentration-1 & & & 71.18 & 66.67 \\
\hline Concentration-2 & Bulk Sample & 20 & 79.37 & 68.70 \\
\hline Concentration-3 & & & 69.54 & 61.55 \\
\hline Final Formula & Mixture with 5 mesh size & 24 & 91.78 & 79.05 \\
\hline
\end{tabular}

As is clear in Figure 2, the bulk sample has an irregular scale deposition. It is expected that, in the experiments with concentration 5 , the rock sample contains more carbonates and sulfides than sulfate minerals. For the same scale composition, a fine sample must have a high dissolution capacity compared to the bulk sample.

The solubility for the mixture scale sample was performed with the common commercial acids used for scale removal. The comparison results are shown in Table 7, which represents the efficient performance for the new scale dissolver to dissolve the scale sample with a high efficiency of $71.2 \%$, and $66.7 \%$ under the temperatures of 45 and $35^{\circ} \mathrm{C}$, respectively. The EDTA (20 wt. \%) and DTPA ( $20 \mathrm{wt}$. \%) showed a lower dissolution efficiency than the new scale dissolver under the same solubility conditions. It is clear from the results that the dissolution efficiency for the new scale dissolver overcame the dissolution efficiency of EDTA ( $20 \mathrm{wt}$. \%) and DTPA (20 wt. \%) by an average of 2.7 times its value at a temperature of $45^{\circ} \mathrm{C}$, while it overcame the dissolution efficiency of EDTA (20 wt. $\%$ ) and DTPA (20 wt. \%) by 4.4 and 3 times, respectively, at a temperature of $35^{\circ} \mathrm{C}$. 
Table 7. Dissolution efficiency with different commercial dissolvers.

\begin{tabular}{cccccc}
\hline Fluid & \multirow{2}{*}{ pH } & \multirow{2}{*}{ Sample } & Time, hrs. & \multicolumn{2}{c}{ Solubility, \% } \\
\cline { 5 - 6 } & & & & $\mathbf{4 5}{ }^{\circ} \mathbf{C}$ & $\mathbf{3 5}{ }^{\circ} \mathbf{C}$ \\
\hline New scale dissolver & 12.5 & & 71.18 & 66.67 \\
EDTA (20 wt. \%) & 12 & Mixture & 20 & 25.21 & 15.05 \\
DTPA (20 wt. \%) & 12 & & & 27.16 & 22.91 \\
HCl (10 wt. \%) & 0.0 & & 1 & 8.00 & \\
\hline
\end{tabular}

$\mathrm{HCl}(10$ wt. \%) was used as a comparative dissolver and showed a dissolution efficiency of $8 \%$ for the scale sample at a low temperature of $45^{\circ} \mathrm{C}$ and $1 \mathrm{~h}$ of exposure time. $\mathrm{HCl}$ interacted efficiently with the carbonate part in the scale.

The new scale dissolver achieved a higher dissolution performance than the $\mathrm{HCl}(10 \mathrm{wt} . \%)$. The observations from the experimental work demonstrated that the $\mathrm{HCl}$ showed no dissolution power after $1 \mathrm{~h}$ of exposure time to the scale sample, and a second observation is that the $\mathrm{HCl}(10 \mathrm{wt}$. \%) interacted only with the surfaces of the scale body which contained more carbonate and was not able to create channels in the body of the scale for more dissolution, but the new scale dissolver was able to.

The scale dissolver was used in a field application to treat a plugged pipeline with scale depositions that restrict and prevent the fluid flow in the pipelines. The scale dissolver was injected into the pipeline, and the scale dissolver succeeded in initiating channels in the scale body like the wormholes created in the reservoir acid stimulation jobs, as shown in Figure 5. The channels helped the scale dissolver to interact more and more with the scale and achieved effective dissolution efficiency for the scale with a high $\mathrm{pH}$ under low-temperature conditions. Therefore, the pipelines were protected from the low $\mathrm{pH}$ acidity corrosion effect.

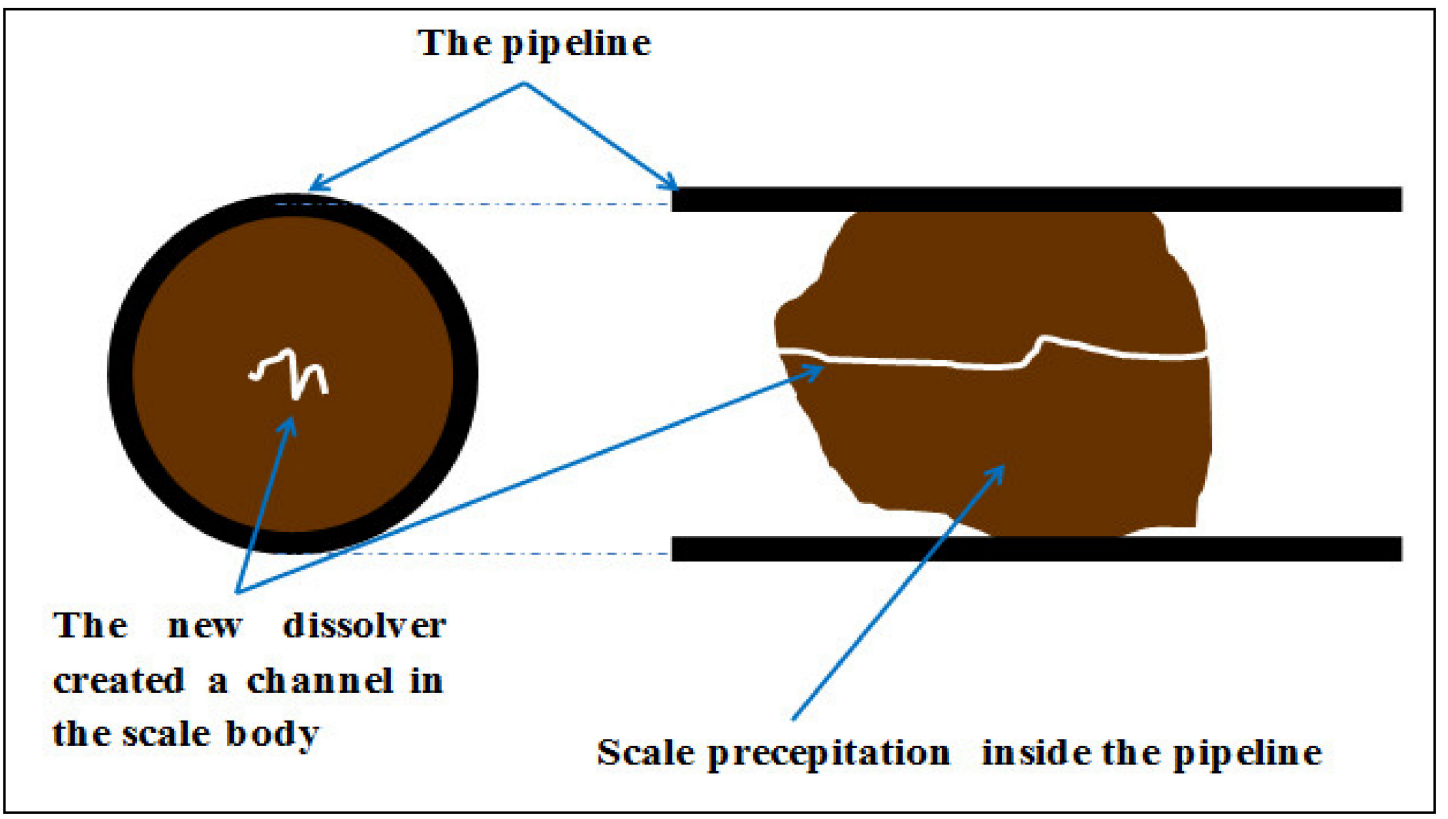

Figure 5. Schematic diagram shows the action of the new dissolver against the scale in the pipeline.

\subsection{Corrosion Test Results}

Actual casing coupons were used in the corrosion test. The new scale dissolver at $\mathrm{pH} 12.5$ was tested for corrosion at $90^{\circ} \mathrm{C}$ for $6 \mathrm{~h}$ using a test vessel at ambient pressure. The corrosion rate was $0.01357 \mathrm{~kg} / \mathrm{m}^{2}$ which is below the recommended limit for the corrosion rate by the oil and gas industry. Therefore, the new scale dissolver performed a non-damaging corrosion effect on the well tubular or the surface facilities and pipelines. 


\section{Conclusions}

In this study, a new non-corrosive dissolver with a high $\mathrm{pH}$ was formulated to dissolve the composite sulfate and sulfide mixture scale at low temperatures. The solubility of the new scale dissolver was performed and compared with other commercial dissolvers. An extensive experimental work was designed and performed to evaluate the new dissolver performance on a real composite scale sample and the following conclusions were deduced:

- The new scale dissolver is able to dissolve the composite mixed scale with $91.8 \%$ efficiency after $24 \mathrm{~h}$ at a temperature of $45^{\circ} \mathrm{C}$ and the dissolution efficiency reached $79 \%$ at $35^{\circ} \mathrm{C}$, with a high pH value of 12.5 ; therefore, the treatment with the new scale dissolver will not affect the integrity of the pipelines;

- The new dissolver can be designed in different concentrations to be optimized with different scale types;

- The dissolution efficiency for the new dissolver showed an efficient solubility performance with fine-scale samples and bulk ones;

- The results showed that the dissolution efficiency for the new scale dissolver outperformed the dissolution efficiency of EDTA (20 wt. \%) and DTPA ( $20 \mathrm{wt} . \%)$ by an average of 2.7 times its value at a temperature of $45^{\circ} \mathrm{C}$, while it overcame the dissolution efficiency of EDTA (20 wt. \%) and DTPA ( 20 wt. \%) by 4.4 and 3 times, respectively, at a temperature of $35^{\circ} \mathrm{C}$;

- The new non-corrosive dissolver outperformed the $\mathrm{HCl}(10 \mathrm{wt}$. \%) for the scale sample at a low temperature of $45^{\circ} \mathrm{C}$. $\mathrm{HCl}$ was found to interact with the carbonate part in the scale sample;

- The corrosion rate for the new low-temperature non-corrosive dissolver was $0.01357 \mathrm{~kg} / \mathrm{m}^{2}$, which is very low and less than the acceptable limit in the oil and gas field;

- The scale dissolver was used in a scale treatment for field application, as it was injected into the pipeline, and the scale dissolver succeeded in initiating channels in the scale body.

Author Contributions: Conceptualization, S.E., and M.B.; methodology, S.E., H.G.; validation, D.A.S. and S.E.; formal analysis, M.B. and H.G.; investigation, S.E., and M.B.; resources, S.E., and D.A.S.; data curation, M.B.; writing-original draft preparation, H.G., M.B; writing-review and editing, S.E., D.A.S., and M.B.; visualization, S.E., and D.A.S.; supervision, S.E. All authors have read and agreed to the published version of the manuscript.

Funding: This research received no external funding

Acknowledgments: The authors wish to acknowledge King Fahd University of Petroleum \& Minerals for giving permission to publish this work.

Conflicts of Interest: The author declares no conflict of interest.

\section{References}

1. Kasnick, M.A.; Engen, R.J. Iron Sulfide Scaling and Associated Corrosion in Saudi Arabian Khuff Gas Wells. In Proceedings of the SPE Middle East Oil Technical Conference and Exhibition, Manama, Bahrain, 11-14 March 1989.

2. Crabtree, M.; Eslinger, D.; Fletcher, P.; Miller, M.; Johnson, A.; King, G. Fighting Scale-Removal and Prevention. Oilfield Rev. 1999, 11, 30-45.

3. Chen, T.; Montgomerie, H.; Chen, P.; Hagen, T.H.; Kegg, S.J. Development of Environmental Friendly Iron Sulfide Inhibitors for Field Application. In Proceedings of the International Symposium on Oilfield Chemistry, The Woodlands, TX, USA, 20-22 April 2009.

4. Kamal, M.S.; Hussein, I.; Mahmoud, M.; Sultan, A.S.; Saad, M.A. Oilfield scale formation and chemical removal: A review. J. Pet. Sci. Eng. 2018, 171, 127-139. [CrossRef]

5. Elkatatny, S. New Formulation for Iron Sulfide Scale Removal. In Proceedings of the Middle East Oil and Gas Show and Conference, Manama, Bahrain, 6-9 March 2017.

6. Bader, M. Sulfate removal technologies for oil fields seawater injection operations. J. Petrol. Sci. Eng. 2007, 55, 93-110. [CrossRef] 
7. Cusack, F. Diagnosis and removal of microbial/fines plugging in water injection wells. In Proceedings of theSPE Annual Technical Conference and Exhibition, Dallas, Texas, 27-30 September 1987.

8. Walker, M.L.; Dill, W.R.; Besler, M.R.; McFatridge, D.G. Iron control in west Texas sour-gas wells provides sustained production increases. J. Petrol. Technol. 1991, 43, 603-607. [CrossRef]

9. BinMerdhah, A.B.; Yassin, A.A.M.; Muherei, M.A. Laboratory and prediction of barium sulfate scaling at high-barium formation water. J. Petrol. Sci. Eng. 2010, 70, 79-88. [CrossRef]

10. Yap, J.; Fuller, M.J.; Schafer, L.; Kelkar, S.K. Removing iron sulfide scale: A novel approach. In Proceedings of the Abu Dhabi International Petroleum Exhibition and Conference, Abu Dhabi, United Emirates, 1-4 November 2010.

11. Li, J.; Li, T.; Yan, J.; Zuo, X.; Zheng, Y.; Yang, F. Silicon-containing scale forming characteristics and how scaling impacts sucker rod pump in ASP flooding. In Proceedings of the Asia Pacific Oil and Gas Conference \& Exhibition, Jakarta, Indonesia, 4-6 August 2009.

12. Senthilmurugan, B.; Ghosh, B.; Sanker, S. High performance maleic acid based oil well scale inhibitors-development and comparative evaluation. J. Ind. Eng. Chem. 2011, 17, 415-420. [CrossRef]

13. Lopez, T.H.; Yuan, M.; Williamson, D.A.; Przybylinski, J.L. Comparing efficacy of scale inhibitors for inhibition of zinc sulfide and lead sulfide scales. In Proceedings of the SPE International Symposium on Oilfield Scale, Aberdeen, UK, 11-12 May 2005.

14. Baraka-Lokmane, S.; Hurtevent, C.; Tillement, O.; Simpson, C.; Graham, G. Development and qualification of new zinc and lead sulphide scale inhibitors for application under harsh conditions. In Proceedings of the SPE International Symposium on Oilfield Chemistry, The Woodlands, TX, USA, 13-15 April 2015.

15. Chilingar, G.V.; Mourhatch, R.; Al-Qahtani, G.D. The Fundamentals of Corrosion and Scaling for Petroleum and Environmental Engineers; Elsevier: Amsterdam, The Netherlands, 2013.

16. Bageri, B.; Mahmoud, M.; Shawabkeh, R.; Al-Mutairi, S.; Abdulraheem, A. Toward a complete removal of barite (barium sulfate BaSO4) scale using chelating agents and catalysts. Arab. J. Sci. Eng. 2017, 42, 1667-1674. [CrossRef]

17. Oddo, J.; Smith, J.; Tomson, M. Analysis of and solutions to the CaCO3 and CaSO4 scaling problems encountered in wells offshore Indonesia. In Proceedings of the SPE Annual Technical Conference and Exhibition, Dallas, TX, USA, 6-9 October 1991.

18. Mahmoud, M.A. Evaluating the damage caused by calcium sulfate scale precipitation during low and high-salinity-water injection. J. Can. Pet. Technol. 2014, 53, 141-150. [CrossRef]

19. Amiri, M.; Moghadasi, J.; Jamialahmadi, M. A prediction of the amount of strontium sulfate scale formation in Siri oilfield at different temperatures and pressures. Energy Sources Part A Recovery Util. Environ. Eff. 2014, 36, 5-14. [CrossRef]

20. Chen, T.; Wang, Q.; Chang, F.F.; Al-Janabi, Y.T. New developments in iron sulfide scale dissolvers. In Proceedings of the NACE International, CORROSION, Vancouver, BC, Canada, 6-10 March 2016.

21. Gamal, H.; Abdelgawad, K.; Elkatatny, S. New Environmentally Friendly Acid System for Iron Sulfide Scale Removal. Sustainability 2019, 11, 6727. [CrossRef]

22. Olajire, A.A. A review of oilfield scale management technology for oil and gas production. J. Petrol. Sci. Eng. 2015, 135, 723-737. [CrossRef]

23. Lu, H.; Kan, A.T.; Zhang, P.; Yu, J.; Fan, C.; Tomson, M.B. Phase stability and solubility of calcium sulfate in the system NaCl/ monoethylene glycol/water. In Proceedings of the SPE International Conference on Oilfield Scale, Aberdeen, UK, 26-27 May 2010.

24. Tung, N.P.; Phong, N.T.P.; Long, B.Q.K.; Duy, N.H. Scale inhibitors for co-deposited calcium sulfate and calcium carbonate in squeeze process in white tiger oilfield. In Proceedings of the SPE International Symposium on Oilfield Scale, Aberdeen, UK, 26-27 May 2004.

25. Jordan, M.M.; Williams, H.; Linares-Samaniego, S.; Frigo, D.M. New insights on the impact of high temperature conditions $\left(176^{\circ} \mathrm{C}\right)$ on carbonate and sulphate scale dissolver performance. In Proceedings of the SPE International Oilfield Scale Conference and Exhibition, Aberdeen, Scotland, 14-15 May 2014.

26. Delorey, J.; Allen, S.; McMaster, L. Precipitation of calcium sulphate during carbonate acidizing: Minimizing the risk. In Proceedings of the Annual Technical Meeting, Calgary, Alberta, 10-12 June 1996.

27. El Menjra, A.I.; Seyeux, A.; Mercier, D.; Beech, I.; Makama, Z.; Marcus, P. ToF-SIMS analysis of abiotic and biotic iron sulfide layers formed in aqueous conditions on iron surfaces. Appl. Surf. Sci. 2019, 484, 876-883. [CrossRef] 
28. Al Tolaihy, M.; Bukhari, D.O.; Wu, A.M. Study on the Optimization of De-scaling Operations in Saudi Arabian Khuff Gas Wells. In Proceedings of the Corrosion 2010, San Antonio, TX, USA, 14-18 March 2010.

29. Wang, Q. Laboratory assessment of tetrakis (hydroxymethyl) phosphonium sulfate as dissolver for scales formed in sour gas wells. Int. J. Corros. Scale Inhib. 2015, 4, 235-254. [CrossRef]

30. Wang, Q.; Ajwad, H.; Shafai, T.; Lynn, J.D. Iron sulfide scale dissolvers: How effective are they? In Proceedings of the SPE Saudi Arabia Section Technical Symposium and Exhibition, Al-Khobar, Saudi Arabia, 19-22 May 2013.

31. Wang, X.; Qu, Q.; Berry, S.; Cutler, J. Iron sulfide removal: A nonacidic alternative to hydrochloric acid treatment. In Proceedings of the SPE European Formation Damage Conference \& Exhibition, Noordwijk, The Netherlands, 5-7 June 2013.

32. Berry, S.L.; Boles, J.L.; Singh, A.K.; Hashim, I. Enhancing production by removing zinc sulfide scale from an offshore well: A case history. SPE Prod. Oper. 2012, 27, 318-326. [CrossRef]

33. Moghadasi, J.; Müller-Steinhagen, H.; Jamialahmadi, M.; Sharif, A. Scale deposits in porous media and their removal by EDTA injection. In Proceedings of the ECI Symposium Series, Tomar, Portugal, 1-6 July 2007.

34. van Domelen, M.S.; Jennings, A.R., Jr. Alternate acid blends for HPHT applications. In Proceedings of the Offshore Europe, Aberdeen, UK, 5-8 September 1995.

35. Da Motta, E.; Quiroga, M.; Aragão, A.; Pereira, A. Acidizing gas wells in the Merluza field using an acetic/formic acid mixture and foam pigs. In Proceedings of the SPE Formation Damage Control Conference, Lafayette, Louisiana, 18-19 February 1998.

36. Smith, P.; Clement, C., Jr.; Rojas, A.M. Combined scale removal and scale inhibition treatments. In Proceedings of the International Symposium on Oilfield Scale, Aberdeen, UK, 26-27 January 2000.

37. Almubarak, T.; Ng, J.H.; Nasr-El-Din, H. Oilfield scale removal by chelating agents: An aminopolycarboxylic acids review. In Proceedings of the SPE Western Regional Meeting, Bakersfield, CA, USA, 23-27 April 2017.

38. Mahmoud, M.A.; Ba Geri, B.; Kamal, M.S.; Hussien, I.A. Removal of Pyrite and Different Types of Iron Sulfide Scales in Oil and Gas Wells without H2S Generation. In Proceedings of the International Petroleum Technology Conference, Doha, Qatar, 7-9 December 2015.

39. Mahmoud, M.; Hussein, I.A.; Sultan, A.; Saad, M.A.; Buijs, W.; Vlugt, T.J. Development of efficient formulation for the removal of iron sulphide scale in sour production wells. Can. J. Chem. Eng. 2018, 96, 2526-2533. [CrossRef]

40. Means, J.L.; Kucak, T.; Crerar, D.A. Relative degradation rates of NTA, EDTA and DTPA and environmental implications. Environ. Pollut. Series B Chem. Phys. 1980, 1, 45-60. [CrossRef]

41. Onawole, A.T.; Hussein, I.A.; Sultan, A.; Abdel-Azeim, S.; Mahmoud, M.; Saad, M.A. Molecular and electronic structure elucidation of $\mathrm{Fe} 2+/ \mathrm{Fe} 3+$ complexed chelators used in iron sulphide scale removal in oil and gas wells. Can. J. Chem. Eng. 2019, 97, 2021-2027. [CrossRef]

42. Ahmed, M.; Onawole, A.; Hussien, I.; Saad, M.; Mahmoud, M.; Nimir, H. Effect of pH on Dissolution of Iron Sulfide Scales Using THPS. In Proceedings of the SPE International Conference on Oilfield Chemistry, Galveston, TX, USA, 8-9 April 2019.

43. Ramanathan, R.; Nasr-El-Din, H. Evaluation of Chelating Agents for Iron Sulfide FeS Scale Removal. In Proceedings of the Abu Dhabi International Petroleum Exhibition \& Conference, Abu Dhabi, United Arab Emirates, 11-14 November 2019.

44. Momoshima, N.; Nita, J.; Maeda, Y.; Sugihara, S.; Shinno, I.; Matsuoka, N.; Huang, C.W. Chemical composition and radioactivity in hokutolite (Plumbian barite) collected at Peito hot spring, Taiwan. J. Environ. Radioact. 1997, 37, 85-99. [CrossRef]

45. Sokhanvarian, K.; Nasr-El-Din, H.A.; Wang, G.; De Wolf, C. Thermal Stability of Various Chelates That Are Used In The Oilfield And Potential Damage Due To Their Decomposition Products. In Proceedings of the SPE International Production and Operations Conference \& Exhibition, Doha, Qatar, 14-16 May 2012.

46. Wehunt, C.D.; Van Arsdale, H.; Warner, J.L.; Ali, S.A. Laboratory Acidization of an Eolian sandstone at 380F. In Proceedings of the SPE International Symposium on Oilfield Chemistry, New Orleans, Louisiana, 2-5 March 1993.

47. Thomas, R.L.; Nasr-El-Din, H.A.; Lynn, J.D.; Mehta, S.; Zaidi, S.R. Precipitation during the acidizing of a HT/HP illitic sandstone reservoir in eastern Saudi Arabia: A laboratory study. In Proceedings of the SPE Annual Technical Conference and Exhibition, New Orleans, Louisiana, 30 September-3 October 2011. 
48. Aljeban, N.; Chen, T.; Balharth, S. Kinetics Study of Iron Sulfide Scale Dissolution. In Proceedings of the Abu Dhabi International Petroleum Exhibition and Conference, Dhabi, United Arab Emirates, 12-15 November 2018; Society of Petroleum Engineers: Richardson, TX, USA.

49. Bageri, B.S.; Mahmoud, M.A.; Shawabkeh, R.A.; Al-Mutairi, S.H.; Abdulraheem, A. Filter Cake Porosity and Permeability Profile Along the Horizontal Well and Their Impact on Filter Cake Removal. In Proceedings of the International Petroleum Technology Conference, Doha, Qatar, 6-9 December 2015.

50. Brezinski, M.M. New Environmental Options for Corrosion Inhibitor Intensifiers. In Proceedings of the SPE/EPA Exploration and Production Environmental Conference, Austin, Texas, 1-3 March 1999.

51. Syafii, I.; Pandya, N.; Sabhapondit, A.; Hajj, H.E. High-Temperature Acidizing: Advantages of InhibitorIntensifier Synergy. In Proceedings of the Abu Dhabi International Petroleum Exhibition \& Conference, Abu Dhabi, United Arab Emirates, 7-10 November 2016.

(C) 2020 by the authors. Licensee MDPI, Basel, Switzerland. This article is an open access article distributed under the terms and conditions of the Creative Commons Attribution (CC BY) license (http://creativecommons.org/licenses/by/4.0/). 